\title{
WASHBACK TO LANGUAGE TEACHERS: A REVIEW OF MODELS AND EMPIRICAL RESEARCH IN AND BEYOND VIETNAM
}

\author{
Dinh Minh Thu* \\ Haiphong University \\ 171 Phan Dang Luu, Kien An, Hai Phong, Vietnam \\ Received 15 October 2019 \\ Revised 23 April 2020; Accepted 24 July 2020
}

\begin{abstract}
Washback, i.e., test effects on teaching and learning, has been emerging as an attractive research topic in language training and assessment for over the past 20 years for its significant implications of test validation and fairness for both policy-makers and practitioners. Presently, it deserves more Vietnamese researchers' interest in the context of the enactment of the National Foreign Language Project 2020 (extended to 2025), which puts language assessment as a key innovation requirement. Washback operates either positively or negatively; i.e. promoting or inhibiting learning. Teachers are considered the precursor in the washback mechanism. There is only one washback model on the washback effects on teachers, which is proposed by Shih (2009). This paper aims to critically browse other washback models besides Shin's (2009) to generate a washback framework on teachers' perceptions and practices. Previous empirical washback research on teachers in and beyond Vietnam is, then, investigated in alignment with the aspects illustrated in the framework to point out achievements and gaps in the field. A qualitative approach of document analysis of over forty studies of differing types, i.e. books, dissertations and articles, has been adopted to reach the research aim. The discussion is divided into two major parts, including the washback models pertaining to teachers to scaffold a model for teachers' perceptions and practices, and the results in empirical research in terms of the aspects mentioned in the model. Findings show that washback on teachers' perceptions ranges from perceptions of the test itself, students' language ability, teaching contents and methodology to teachers' professional development. Plus, washback on teachers' practices concerns their selections of teaching contents and methodology in class as well as their involvement in professional development. The element of professional development can be considered a new light in the reviewed washback model. This has a significant meaning by raising teachers' awareness of developing themselves professionally. The current paper expects to contribute to elaborating the scenario of washback research for interested researchers, practitioners and policymakers not only in but beyond the context of Vietnam.
\end{abstract}

Keywords: washback, washback models, language test, teacher perceptions, teacher practices

\section{Introduction}

${ }^{1}$ Washback, i.e., test effects on teaching and learning, has been attracting numerous researchers like in the world, including Vietnam (Alderson an Banerjee, 2001; Bui,

\footnotetext{
* Tel.: 84-912362656
}

Mail: thudm@dhhp.edu.vn
2016; Bui, 2018; Cheng \& Curtis, 2012; Nguyen, 2017; Hsieh, 2017; Tayeb, Abd Aziz \& Ismail, 2018; Wall \& Horák, 2006; Wenyuan, 2017). According to Cheng, Sun, and Ma (2015, p. 440), the popularity of washback was justified by its effect on test fairness and validation. It is undeniable that teachers are the precursor in the process of 
teaching and training. This argument raises the need of studies on washback on teachers, who can create positive washback in class to promote learning. Documentation has recorded washback models proposed by Alderson and Wall (1996), Bailey (1996), Hughes (2003), Green (2007) and Shih (2009). Nonetheless, there leaves a gap of a single washback research review which updates the washback theories and empirical findings from the teacher aspect. The current study aims to fill into that gap by answering two research questions as follows:

1. What is the shape of the updated test washback model on English language teachers' perceptions and practices?

2. How have the aspects in the updated model been studied?

The research expects to provide a new look into the washback reseach area for English language assessment not only in Vietnam but beyond the country.

\section{Methodology}

The qualitative approach is applied to this review via a document analysis of the previous research on washback theories and practices. The literature was analysed and evaluated critically in accordance with the research questions. The research started with the definitions of washback, teachers' perceptions, and teachers' practices. The major research part embraced the critical revision of recognized washback conceptual frameworks, from which a new conceptual framework for washback to EFL teachers' perceptions and practices was built. Plus, it reviewed the empirical findings on the bases elaborated in the fresh framework.

\section{Theoretical background}

\subsection{Washback concepts}

Washback (backwask) has been largely defined in applied linguistics. The most general concept of washback can be "the effect of testing on teaching and learning" (Hughes, 2003, p.1). More specific concepts can identify the individuals involving in the washback mechanism or/and the context washback occurs in. Washback refers to "the impact of external language tests to affect and drive foreign language learning in the school context" (Shohamy, 1993, p. 153); "the direct impact of testing on individuals" (Bachman \& Palmer, 1996, p. 30); the force for "teachers and learners to do things they would not necessarily otherwise do because of the test" (Alderson \& Wall, 1993, p.1); or "a part of the impact a test may have on learners and teachers, on educational systems in general, and on society at large" (Hughes, 2003, p. 53). These definitions point out teachers, students and other stake-holders like authorities and parents who are affected by the test powers. Also shown from these concepts, washback can operate either "in the school context" (Shohamy, 1993, p.153) or even in the society (Hughes, 2003). In addition, Pierce (1992, p. 687) contributed to washback definitions by stating that it is "the impact a test has on classroom pedagogy, curriculum pedagogy, curriculum development and educational policy". His definition is interested in teachers and policy makers rather than learners through the words of "pedagogy" and "policy". Another interesting point of view on washback was Pearson's (1988, p. 7), cited in Cheng et al. (2004): "Public examinations influence the attitudes, behaviours, and motivation of teachers, learners, and parents, and because the examinations often come at the end of a course, this influence is seen as working in a backward direction, hence the term, washback." Pearson' (1988) point of view comprises both the cognitive features like attitudes and motivation and the practice or behaviour. This research 
concerns washback effects on teachers in the school context since "teachers are "the 'frontline' conduits for the washback processes related to instructions" (Bailey, 1996, p.17). The above analysis yields a clear shape of washback which means the test influence on teachers' cognitive mechanism and actions to reach the educational goals. This research conceptualizes washback as the classroom impact of tests on teachers' perceptions and practices toward teaching and learning.

\subsection{Teachers'perception}

Teachers' perceptions, one of the two focal points of the current study, have been mentioned in Alderson \& Wall's (1993), Hughes' (2003), Green's (2007) and Shih's (2009) washback theory. However, little effort has been made to define in teachers' perceptions in relevance to washback effects. In empirical research on teachers' perceptions, the words of "perceptions" and "beliefs" are used interchangeably (Wang, 2010; Onaiba, 2013; Mahmoudi, 2013; Antineskul \& Sheveleva, 2015; Cheng, 1999; Hsu, 2009; Liauh, 2011; Salehi et al., 2012; Cheng, 2004) without much effort in defining perceptions but beliefs.

With regards Cambridge Dictionary, perception is defined as "a belief or an opinion" or "an understanding". Instead of providing a thorough insight into perceptions, cognition researchers have widely discussed the term beliefs (Pajares, 1992; Borg, 2003; Zeng, 2015). There is inconsistency in defining teachers' beliefs. While Green (2012) and Richardson (1996) cited as Le (2011) distinguish beliefs from attitudes and knowledge, Borgs (2003) and Pajares (1992) consider beliefs knowledge, perceptions and attitudes. Then, perceptions can be understood through the definitions of beliefs. Rokeach (1969) as cited in Le (2011) sets beliefs as an "integrated cognitive system" or "any simple proposition . . . inferred from what a person says or does, capable of being preceded by the phrase "I believe that ..." Pajares (1992, p. 316) defines beliefs as an "individual's judgment of the truth or falsity of a proposition, a judgment that can only be inferred from a collective understanding of what human beings say, intend, and do". Richardson (1996, p. 102) names beliefs "a subset of a group of constructs that name, define, and describe the structure and content of mental states that are thought to drive a person's actions". Perceptions belong to these constructs. Borg $(2003,2006)$ states teachers' beliefs are the cognitive and systemic nature of beliefs: what teachers think, know or believe.

In washback research, teachers' perceptions are grounded on the label "attitudes", "feelings" (Mahmoudi, 2013; Tsagari, 2011), "beliefs" (Mahmoudi, 2003, Wang, 2010), "understanding" (Cheng, 2004; Hsu, 2009). Antineskul \& Sheveleva (2015), reflected the research on teachers' perceptions with the words "attitude", "think", "like", and "know" repeated many times (p. 8 -12). Onaiba (2013, p. 56) accredits perception washback to feelings, beliefs, attitudes toward the test. Only Mahmoudi (2013) mentions perceptions and attitudes separately from the title of his research, and only Green (2013) talks about beliefs, not perceptions. Green (2013, p. 46, 47) raises specific questions on teachers' beliefs about teaching and about testing. Regarding teaching, they are teachers' beliefs of effective teaching strategies and their compatibility with the test demands, of test preparation challenges and of "local precedents" for that preparation.

From the above review, teachers' perceptions of teaching under the influence of the test denote how teachers feel, think about, 
believe and understand the test and their classroom teaching practices.

\subsection{Teachers'practices}

Almost all previous empirical washback studies have excluded the review of teachers' practices, but perceptions. Barnes (2017) seems to be the single washback researcher who discusses the relationship between communicative language teaching (CLT) and high-stakes language testing prior to the methodology part and other subsequent parts. Hsu (2009) provided "teachers' behaviors" as "what teachers do in the classroom" (p.88), and he studied teachers' medium of instruction, teacher talk, teaching activities, teaching materials and lesson planning. The deficiency in definitions of teachers' practices in washback research may imply the researchers find tests in teaching rather than teaching in tests. It can be argued that when relevant teaching theories are discussed in a washback study on teachers' perceptions of teaching and their actions, from which teaching aspects come into lights to facilitate the evaluation of teaching effectiveness in the introduction of a new test.

Concerning teachers' effectiveness, Danielson (1996) presents a teaching framework of four domains, including Planning and Preparation, Classroom Environment, Instruction and Professional Development. The three first domains concern teachers' direct actions in class, while the fourth and last domain enhances the quality of direct actions. The planning and preparation section requires teacher knowledge of content, methodology, students, resources and assessment. The second domain pertains to teachers' ability to creating and managing a class which fosters learning. The third domain refers to teachers' oral ability to engage students in learning and teachers' assessment conduction. The professional aspect demonstrates teachers' activities to better students' learning by reflecting their classwork, communicating with parents, joining the professional community and showing evidence of professional development. These practices can go along with the perception aspects as mentioned in the previous part; i.e. teaching contents, teaching methods and professional development.

English teaching contents vary in different contexts of different purposes and resources. English teaching methods, on the other hand, have undergone three common trends, including traditional approaches before 1960s, classic communicative approaches between 1970s and 1990s, and modern communicative approaches from the late 1990s till now (Richard, 2006, p.6). Plus, the late part of the twentieth century introduces the post-method (Kumaravadivelu, 1994; Richards \& Rogers, 2001; Chen, 2014). The oldest approaches prioritise the mastery of grammatical rules, featured by Grammar-translation Method, Direct Method, Audiolingualism (Aural-Oral Method), and Structural-Situational Approach (Situational Language Teaching) (Richard, 2006; Brandle, 2008). The Grammartranslation method focuses on grammar and vocabulary and these language aspects are normally taught deductively. It is derived of developing students' communication in the target language. The Direct Method becomes its opponent, which refutes translation into the mother tongue, but a direct exposure to the target language with oral communication built carefully through teacher-students' exchanges in intensive classes. The language teaching principle evolves to the Audiolingualism, which the presentations of language chunks which are repeated and memorized in its natural context. The Situational Method follows the P-P-P model (presentation- 
practice-production), in which grammar is taught from the context of a text. However, these methods fall out of fashion because they are hard to have students use language meaningfully and fluently. A focus on separate items of grammar and vocabulary gives the way to a development of communicative competence for communicative purposes like making requests and describing needs, etc. Communicative syllabi are developed with the skill-base and function-base. Nonetheless, classic communicative approaches continue growing till the present. If the classic style is limited to sets of fixed principles, modern communicative teaching, while still placing its emphasis on language users' communicative competence, is more flexible. In reality, teachers may not follow a single method. Or else, they think they are using this method, but in fact their activities illustrate another method. Nonetheless, the diversity in methods are adopted as long as they boost up the student use of language in communication.

\subsection{Popular washback models}

Alderson \& Wall (1993) are accredited as pioneers to build up the first popular washback theory, followed by Hughes (2003), Bailey (1996), Bachman \& Palmer (1996), Green (2007) and Shih (2009). Washback aspects pertaining to teachers and their teaching will dominate the discuss room herein, basing on the present research objectives.

In Alderson \& Wall's (1993) fifteenhypothesis framework, eight hypotheses mention the influence of the test on teachers and teaching. A very general statement is claimed first: a test will affect teaching, tailing specific affecting factors embracing teaching contents, methods, rate, sequence, degree and depth of teaching. These authors also state that a test will affect different teachers differently. This is later empirically explained with various washback effects on different teachers in diversified contexts.

Components of washback appear more obviously in models by Hughes (2003), Bailey (1996) and Green (2007). Washback appears in the trichotomy of participants, process, and products, which "may be affected by the nature of a test" (Hughes, 2003, p.2). The author widens the range of participants as language learners and teachers, administrators, materials developers, and publishers, whose perceptions, attitudes, motivations and actions can be impacted by the test. He defines process as any of participants' behaviors serving learning goals, including materials development, syllabus design, changes in teaching methods or content, learning and/ or test-taking strategies, etc. Finally, product covers the learnt contents and their quality.

Three years later, Bailey (1996, p. 264) develops Hughes' (2003) trichotomous model into a washback framework portraying the complicated reciprocal interactions among all the components, commencing from the test and ending in it, too. A new participant as researchers is involved; however, "researchers" and "material writers and curriculum designers", compared to "students" and "teachers", are far from direct teaching and learning. Furthermore, the test affects teachers; and teachers, in turns, implement their teaching. In contrast, teachers also exert their impact on the test. This is possibly true in case teachers have the right to make changes with the test, but not true in all situations. In the model, "participants" and "products" enjoy four corresponding labels each. "Process", in other words learning/teaching/designing/ researching, enables "participants" to actualize their "products". The question how the process takes place will be of great importance to 
guide washback researchers; hence, it requires immense elaborations by the followers.

In the same year 1996, Bachman \& Palmer (p. 147) provide aspects concerning washback to teachers by questioning the consistence between (i) "the areas of language ability to be measured" and "those that are included in teaching materials", (ii) "the characteristics of the test and test tasks" and "the characteristics of teaching activities", (iii) "the purpose of the test" and "the values and goals of teachers and of the instructional program". Content factors are taken into considerations, i.e. gauged language skills and taught ones, test characteristics, teaching practices. Furthermore, point (iii) in their theory can share several values with Alderson \& Wall's (1993) theory. Stated from this perspective, washback is shown when test characteristics are validated, and there is a link amongst the test content and syllabus content as well as teachers' beliefs and practices.

In 2009, Shih (p. 199) presented the most detailed washback model of washback to teaching. The advanced aspect of the test is the dynamic convergence of well-listed contextual factors, test factors and teacher factors to impact teaching practices. The author adds letter " $\mathrm{t}$ " as a sign of the changing nature of washback over time. According to Shih (2009, p. 200) the italicized factors are significant in her research, while the underlined ones are her new recommendations. The first component is analysed into three layers from the national factors to the school factors and then to the course level. Washback, addressed in this way, can be said to extend its scope to impact as discussed in the part of washback concept above. Test factors, including the test status, test content, test quality, etc. are claimed to directly affect teachers' inherent factors and teachers' teaching practices. Teacher factors, illustrated by their educational background and present perceptions of the test status and test quality, etc. will be reflected in their teaching. In this model, teaching aspects are shaped vividly, in comparison to other frameworks, which can be described in terms of teaching contents, teaching methodology, and even psychological features. Great efforts would be needed to specify the information in the box washback of tests on teaching. If Bailey (1996) presents the two-sided impact between the test and the participants, Shih (2009) uses one-sided arrow targeting washback of the test to teaching. Possibly, washback of the test has its significant meaning in giving feedback to the policymakers and the test users, teachers included, from which positive changes may happen.

Overall, the washback mechanisms have developed from Alderson and Wall's (1993) radical framework stating the influence of the test on teachers in terms of teaching contents, methodology, degree, depth, as well as teachers' attitude towards these aspects to Shin's (2009) more complicated model showing various complicated washback facets. The washback degree and scope will vary regarding personal factors and contextual factors, which need detailed studies in differing institutions.

\section{Results \& Discussion}

\section{1. The updated washback framework.}

Up to now, six washback models by Alderson \& Wall (1993), Bachman \& Palmer (1996), Bailey (1996), Green (2007), Hughes (2003), and Shin (2009) have been critically reviewed, with the focus on aspects pertaining to teachers and teaching. The conceptual framework of washback for this research is formulated from the integration of the above mechanisms to investigate washback of a test, EAT, to teachers' perceptions and practices at a university in Vietnam. Teachers' perceptions 
of students' level and motivation have certain impacts on their practices (Chen, 2002; Furaidah et al. 2015).

The conceptual framework is original in the way the components are organised as well as the addition of an element of teachers' professional development. This new factor is significant when it is commonly agreed that teachers play as a driving force in producing positive washback (Bailey, 1996, Liauh, 2011; Tsagari, 2011; Ahmad \& Rao, 2012; Onaiba, 2013; Antineskul \& Sheveleva, 2015; Spratt, 2005). It is also significant in the Vietnamese context when the National Foreign Language Project emphases improving teachers' capacity, but there is deficiency in researching how teachers perceive the mission and how they practice it. $\mathrm{Vu}$ (2016) is one among few authors mentioning assessment as a trigger for professional development (PD), but numerous challenges are found out. For example, teachers found PD was "too difficult", they "don't have enough time", they "haven't got anything that's really of interest"; and they were "not yet confident enough" (p. 123)

In the washback model, the test is the focal part of this study framework with its constructs and characteristics. There is only one participant role of teachers in relation with their characteristics and values which are linked to their perception of the test status as well as test difficulty.

\begin{tabular}{|c|c|c|}
\hline \multicolumn{3}{|c|}{ TEST WASHBACK TO TEACHERS } \\
\hline $\begin{array}{l}\text { Perceptions of the test } \\
\text { and students }\end{array}$ & Perceptions of teaching & Teaching practices \\
\hline 1. Test status & 1. Teaching contents & 1. Teaching contents \\
\hline 2. Test purpose & 1.1. Materials & 1.1. Materials \\
\hline 3. Test quality & 1.2. Skills & 1.2. Skills \\
\hline 4. Test resources & 2. Teaching methodology & 2. Teaching methodology \\
\hline 5. Students' language & 2.1. Teaching approach & 2.1. Teaching approach \\
\hline capacity for the test & 2.2. Instructional language & 2.2. Instructional language \\
\hline 6. Students' attitude & 2.3. Instructional time & 2.3. Instructional time \\
\hline $\begin{array}{l}\text { learning English in } \\
\text { general }\end{array}$ & $\begin{array}{l}\text { 2.4. Time allocation in differing } \\
\text { skills }\end{array}$ & $\begin{array}{l}\text { 2.4. Time allocation in } \\
\text { differing skills }\end{array}$ \\
\hline 7 Students' attitude and & 2.5. In-class assessment & 2.5. In-class assessment \\
\hline $\begin{array}{c}\text { motivation toward the } \\
\text { test }\end{array}$ & $\begin{array}{l}\text { 3. Teacher professional } \\
\text { development }\end{array}$ & $\begin{array}{c}\text { 3. Teacher professional } \\
\text { development }\end{array}$ \\
\hline & 3.1. Teachers' self-training & 3.1. Teachers' self-training \\
\hline & $\begin{array}{l}\text { 3.2. Teachers' collaboration } \\
\text { with on-site colleagues }\end{array}$ & $\begin{array}{l}\text { 3.2. Teachers' collaboration } \\
\text { with on-site colleagues }\end{array}$ \\
\hline & $\begin{array}{c}\text { 3.3. Teachers' socialization } \\
\text { with the external professional } \\
\text { community }\end{array}$ & $\begin{array}{l}\text { 3.3. Teachers' socialization } \\
\text { with the external } \\
\text { professional community }\end{array}$ \\
\hline
\end{tabular}

Figure 1. A conceptual framework for test washback to teachers' perceptions and practices 
The interaction among these factors are very complicated, which can only be shaped in a detailed study. It can be argued that the perceptions and practices teachers reveal can return as determinant factors to improve the quality of the test. However, the current research is restricted to the impact of the test to teachers before the test event.

\subsection{Empirical research on washback to EFL teachers'perceptions and practices}

\subsubsection{Washback of the test to teachers' perceptions of the test and the students}

The implementation of the test exerts washback to teachers' perceptions of the test itself and the students who are the test takers in different ways. Generally, high-stakes tests attract more attention than their low-stakes counterparts, and students of better language abilities seem to attract more teachers' investment of test tasks (Shohamy, 1993; Tsagari, 2007; Chen, 2002; Cheng, 2004).

Regarding teachers' knowledge, attitudes and beliefs of the test, negative reports are founded in most of the research (Hughes, 2003; Shohamy, 1993, Tsagari, 2007; Wang, 2010; Mahmoudi; 2013; Onaiba, 2013; Tayeb et al, 2018, etc.). Hughes (1998) in the context of Turkey, reported teachers' negative attitudes toward the test because it caused their tensions and anxiety. Shohamy (1996) found out the same results with an Arabic test in Isareal. Teachers felt degraded when the test did not help them in their future teaching but demand them. As for the test quality, teachers were not consulted before the final test was designed, which led to their feeling of humiliation and the thought of discrepancies between the test quality and the students' ability. Tayeb et al. (2018) from Yemen was in line with Shohamy (1993) when they reported teachers' bad feeling toward the test because "they were passive when test design, administration and evaluation depends on the High committee of examination" (p.454). In terms of the test status, teachers expressed opposing attitudes toward the Arabic exam, but supports for the EFL exam because the latter could effectively back up students' communicative skills and their future. Despite their positive attitude, teachers suffered from an overloaded volume of materials and stress on students' success or failure (Shohamy, 1996). Shalehi \& Yunus (2002, cited in Mahmoudi, 2013) intesified this deleterous impact on teachers in the enactment of the Irannian National University Entrance Exam (INUEE) in Iran. Most teachers in Lybia also held negative attitudes toward the test (Onaiba, 2013). They thought the new examination had a low quality. It was not effective in either evaluating students' integrated skills or preparing students' language use in the future. Even though, the test was not in alighment with the curiculum content, which could be called "underrepresentative". The negative perception of the test and the resistance to change is also reflected by Wang (2010) in his washback research of the revised CET in China. Plus, Alderson \& Hamp-Lyon (1996) and they pointed out that a large number of teachers are stressed under the feeling of guilt and frustration when they felt it hard to provide interesting language lessons and helping students get their expected score. Thuy Nhan (2013) investigated the impact of TOEIC ${ }^{\circledR}$ as a university graduation conditions in Vietnam reflected teachers demotivation in the implementation of the test as well as suitability in the context. However, other researcher saw a light scenario. Cheng (2004) from Hong Kong got the evidence of a majority of teachers' positive attitude toward $\mathrm{HKCEE}$ albeit to a superficial change in their core beliefs and initial pressure. Saville (2009), Tsagari (2011), 
Antineskul \& Sheveleva (2015) supported Cheng. Antineskul \& Sheveleva (2015, p. 7) justified the reason for teachers' good feeling toward the test Business English Cambridge (BEC) because it was "a new course" to try, had "extra pay", "exam's popularity among students" and "relevance to main curriculum". In terms of the test resources, globallyrecognised tests like TOEFL or IELTS enjoyed rich resources (Wall \& Horák, 2006; Read and Hayes, 2003; Shohamy, 1998; Saif, 2006; Tsagari, 2011; Peña Jaenes, 2017) while other test types, especially achievement tests were not of this benefit. Possibly, this would caused difficulties to teachers to get a better insight of the test to have more appropriate actions. Plus, Antineskul \& Sheveleva (2015) showed teachers believed the test could enhance their professional development opportunity students' future job opportunity and university's reputation. In terms of their perception of teaching BEC, teachers' exam preparations generate advantages.

"Still, even though their reactions might be "no difference in teaching", the respondents unanimously admit that BEC preparation has a positive influence on their teaching. The particular semantics of explanation include "goal-orientation of BEC exam", "individual approach to teaching English", "preparation of teaching materials", "teachers' (improved) knowledge of content language", "variety of teaching materials and tasks for students", "more time-efficient teaching", "ability to motivate students with the content", "justifying students' tuition costs", "developing teaching techniques for exam skills"Antineskul \& Sheveleva (2015, p. 9).

Both negative and positive perceptions are also repored by Mahmoudi (2013) with INUEE although the former overwhelmes the latter. Two in six informants thought the test to be able to test universversity applicants' academic language knowledge while the remanining douted its evaluation value of true language proficiency but route-learning. Li's (1990, cited in, Tsagari, 2007) study on washback of NMET to teaching pointed out that in terms of perceptions, teachers had a negative feeling toward the new test first, but changed to a positive attitude in a few years later and thought it could assist their methodology reform at the classroom level. Bui (2016) discussed teachers' perception of English language teaching in high school in Vietnam under the influence of the Vietnam's College English Entrance Exam (VCEE) merely as one part of her research on that test usefulness. Teachers are asked on two themes: the test difficulty and quality. Most respondents thought the test challenged average students, but it covered the textbook contents. By contrast, less than one fifth of them frowned upon the ability to measure test takers' communication skills, but reading skills, grammatical and lexical knowledge. The quality of the test was relatively fine.

Teachers' perceptions of students' language level can guide their practices. Chen (2002) ffound that if teachers believed students possessed a better ability, they would invest more in them to help them reach the target. By contrast, Furaidah et al. (2015) revealed that teachers' perceptions of students of lower-level would entail their more drilling activities and less communicative ones.

The review of teachers' perceptions of the test and the students uncovers differing, even contrasting research outcomes with justifications in unique contexts. The test status and quality, students' language ability have been mentioned. Nonetheless, other important factors like the availability of test resources, students' motivations towards 
learning English and towards the test have not reached. These gaps open future research on washback.

\subsubsection{Washback of the test to teachers' perceptions of teaching}

This part would share simlilar features with the part reviewing teachers' practices in different ELT contexts. However, they are distinctive in such a way that these aspects are reported from researchers' interviews and questionnaires delivered to teachers to reveal their beliefs about teaching, not their actions serving teaching, which would be better investigated in observations, and questionnaires, interviews as well.

The perceptions of teaching are found diversified in terms of teachers' academic and professional experience (Mahmoudi, 2013; Lam, 1994; Shohamy, 1996; Watanabe's (2004). The more experienced teachers are, the more test-oriented their perceptions of teaching are.

On answering the question on teaching contents, teachers believed that if the textbooks have the contents in alignment with the test tasks, they preferred to use them (Onaiba, 2013; Tran, 2016). Other respondents perceived the inadequacy in the textbooks resources; hence, supplement materials were exploited. Li (1990, cited in, Tsagari, 2007) found teachers shifted from linguistic knowledge to communicative ability, supported by imported authentic textbooks and reading materials, which could be a good sign for students' language ability development. Bui (2016) saw the test covered the textbook contents, but teachers used more grammar and vocabulary exercises and less reading, speaking, writing and listening and phonology exercises for students. Negative washback revealed in more linguistic knowledge being focused while less language skills were drilled. Sadighi et al. (2018) found out that teachers believed the textbook used for the university entrance exam in Iran would generate beneficial productions of language, but supplementary materials to prepare students for the test would be used more. They percieved that the syntactical and lexical points in the textbook needed modifying because they were demotivating. They also questioned the textbook which followed the test goal but lacked communicative effects.

With regards teacher' beliefs of teaching methodology, diversities were also reported. Sadighi et al. (2018) found out that teachers spent most of their class time instructing students tasks which were relevant to the test. More time was devoted to grammar explanation and practices. Onaiba (2013, p. 246) showed teachers' acceptance of the new exam tasks to alter their teaching methods. Wall \& Horák (2006) questioned the reliability of classroom assessment. Simulation tests are employed but the test condition is not standard. Due to less communicative ability in English is required, teachers perceived that Vietnamese as a means of instruction was more popular in language classes (Bui, 2016). Mahmoudi (2013) found out that experienced teachers owned the perception that INUEErelated tests and materials should account for more class time. Experienced teachers were more exam-oriented than less eperienced counterparts (Lam (1994; Shohamy, 1996).

Washback to teachers' aspects of teaching is not limited to teaching contents and teaching methodology, but is extended to teachers' professional development, because this can contribute to their perceptions and actions. There exists a big gap of the issue in the reviewed research, except few words voiced by Wall \& Horák (2006), Thuy Nhan 
(2013), and Antineskul \& Sheveleva (2015). While Antineskul \& Sheveleva (2015) showed teachers believed the test could enhance their professional development, Thuy Nhan (2013) showed teachers' demotivation in their profession due to the test. She linked teachers' professional reputation to the rate of successful/failed students in the exam. A majority of teachers were under pressure when they lacked professional training opportunities of the test but they were assigned to teach how their students could achieve a target score. Wall \& Horák (2006) was in line with her.

The above discussion depicts teachers' perceptions of teaching in terms of three aspects: contents, methodology and carreer intensification. Teachers believed in direct teaching to the test with aligning materials, skills and teaching techniques. Nevertheless, many issues in the present study framework has not been reached fully, especially in the area of teachers' development.

\subsubsection{Washback of the test to teachers' practices}

A huge volume of research has been conducted on the impact of the test on teachers' practices, releasing rich sources of information of both positive and negative washback.

Researchers found in most cases textbooks reflected the (previous) exam formats; hence, teachers use them (Wall \& Horak, 1996; Onaiba, 2013; Wantanabe, 2004; Barnes, 2016). For example, Hamp-Lyons (1997) saw the persent textbooks consisted of test-taking strategies and mastery of language grammar, vocabulary and other linguistic features of the previous TOEFLs. Wall \& Horak (1996) echoed Hamp-Lyon' view about TOEFL materials. This led to a situation in which Lam (1994) raised the problem of teacher exam/ textbook slaves. It may bebe better if authentic materials are brought into the classroom, rather than such commercial materials. Barnes (2016, p. 170) cited Widdowson's (1981) distinction between 'goal- oriented courses' and 'processoriented courses' to argue that the TOEFL test preparation course features the first type; therefore such teachers' practices were quite justifiable. The instrumental textbooks emerge the closely neat cooperation between test designers and textbook developers to make sure the communicative constructs. On the other hand, these materials should be adapted to the contextual factors like students' needs and students' level. Furaidah et al. (2015) investigated washback to non-likeENE(English national examination) materials and like-ENE materials with the shift to the former in the later part of the course, especially for better students. Students' level affected teachers' choice of materials. Low-level students benefited from materials within their capacities. Saif (2006) had evidence of teachers' alignment beween materials and students' needs as well as test purpose. Supplement materials are used to compensate for inadequate linguistic knowlege, i.e, grammar and vocabulary, in the text book (Wall \& Horák, 2006). Anderson, Wall and Hamp-Lyon (1993, 1996) showed that teachers narrowed down or abandon their textbooks for intensive work with past papers and commercial publications to prepare their students for the exam. Like Alderson \& Wall (1993, 2005), Tsagari (2011), Onaiba (2013), Salehi, Unus \& Salehi (2012) Saif, (2006), Read and Hayes (2003), Cheng (2004) saw teachers change their teaching contents under the influence of the test. This happens to tests which have rich and systematic sources like TOEFL or IELTS (Wall \& Horák, 2006; Read and Hayes, 2003; Shohamy, 1993; Saif, 2006; Tsagari, 2011; Peña Jaenes, 2017). Teachers contrentrated on manifesting the test 
tasks due to of time limitation and workload. Skills to teach were narrowed down to those to be tested in the test. For example, teachers narrowed down the learning skills by focusing on listening and reading (Furaidah et al., 2015). Or, listening and writing which are not tested, are excluded in teaching (Rahman, 2014). Wall \& Horák (2006) observed classrooms, seeing that teachers realized listening strategies but did not breakdown them into teachable skills (p.108). Reading was used as homework. Grammar and vocabulary were taught in points. That means linguistic knowledge is prioritized to communicative skills. In Vietnam, Thúy Lan Nguyễn (2017) conducted a study on washback of VSTEP , reporting positive washback from the exam. It classified students of different language skills at different levels, which acted as a guideline to design the curriculum.

More specifically about methodology, most classed are reported teacher-centered with traditional methods. (Alderson \& Wall, 1993; Wang, 2010; Onaiba, 2013; Tsagari, 2011; Taqizadeh \& Birjandi, 2015). Barnes (2016) revealed the dominant role of teachers in class, the heavy reliance on commercial TOEFL materials and the limited class activities. It is interesting to see Furaidah et al. (2015, p.49) pointed two types of teaching, including regular teaching (students-oriented) and drilling teaching (teacher-oriented/ testoriented for different phase to approach the final test. The classroom interaction in the second phase was described as the teacher questioning-student answering time. Wang (2010) in his washback research of the revised CET. There are gaps between the information collected from the survey and that from the observations. For examples, while the interview reported the positive shift in methodology, teachers' actions in class were still teacher-centred. Although new books designed communicative activities in speaking lessons, teachers still skipped them and maintained the knowledge transformation mode like in the old version. While $69 \%$ of teachers perceived the detrimental impact of tests on teacher, $65 \%$ considered CET a student's learning driving force (Wang, 2010, p. 190). A number of contradictions in teachers' perceptions and actions have been pinpointed in the research, which means that washback is a too complicated matter, and data triangulation is necessary. He concluded that the revised CET did almost no change in teachers' beliefs and practices (Wang, 2010, p. 215). Thuy Nhan (2013) saw teachers increase their class involvement to both attaining curriculum goals and supporting students' achieving the TOEIC ${ }^{\circledR}$ certification. They had more power in their language class and make more careful decisions concerning teaching and assessment. Thúy Lan Nguyễn (2017a) reported significant changes in pedagogical class activities when teachers shifted students to active learning via project learning and integrative learning. Specifically, testing and assessment in light of VSTEP varied its forms, emphasizing on continuous assessment. Also concerning assessment, Onaiba (2013) reported the use of mock exams, especially when the exam comes closer. Time allocation during course is also a matter of concern. Furaidah et al. (2015) reported time division was decided by the policy makers with more time for the later part of the course. However, it is important to know how teachers themselves spend their own time budget in their own class. No other other research paid attention to this while different time allocation on different parts of study can results in different washback intensity level. In addition, L1 as instructional language was popular in language classes (Onaiba, 2013; Bui; 2016; Salehi, Unus \& Salehi, 2012). The reasons for using mother tongue were to save 
time and to address low level students.

Now it comes to the issue of professional development with little information revealed, except in Thuy Nhan (2003), Wall \& Horák (2006) and Antineskul \& Sheveleva (2015). Although Antineskul \& Sheveleva (2015) showed teachers believed the test could enhance their professional development, they lack the detailed descriptions of the activities. Thuy Nhan (2003) and Wall \& Horák (2006) complained very limited professional development opportunities for teachers at the studied universities. More evidence should be found on this to see how teachers develop their career themselves and in the communities, from which policy makers can have appropriate actions to build up their employeees' capacity.

The documentation of washback of English tests to teachers' practices have called out the current situations of the impact of the test to teaching, as well as pointed out research gaps. Teaching contents tend to be twisted with the test contents and test format, but teaching methodology seems to be more stative. Traditional methods are more frequently reported than communicative methods. This is in line with Cheng's (1997) remark that washback is more dominant in teaching materials than methodology. Once again, the matter of teachers' time allotment or teachers' professional development has been left less touched.

In conclusion, two major flaws of previous research papers can be enumerated as follows. First, washback to teachers' perceptions has been discussed widely; nonetheless, little information about the way teachers perceive their students' language ability, motivation and their actions on professional development and the way they give instructions in class and practice professional development. Thirdly, washback studies tend to concern highly- recognised exams, IELTS, TOEFL or EUUs, for example, while leaving smaller-scale tests like achievement ones nearly untouched. Further research are hoped to fill into the research gap.

\section{Conclusions}

In conclusion, the current research has managed to scaffold a new theoretical framework of the test washback to teacher perceptions and practices. Popular washback theories suggested by Alderson and Wall (1993), Hughes (2003); Bailey (1996), Bachman \& Palmer (1996), Green (2007) and Shih (2009) have been analysed, focusing on teacher factors. The updated framework are composed of three aspects, namely teachers' perceptions of the test and the students, teachers' perceptions of teaching and teachers' practices. A subsequent review of empirical research on washback in various contexts reveals several research gaps for further research agenda. Test validity can be studied as a base for the washback research. Teacher professional development under the test impact has been largely researched. Plus, more washback research focuses on high-stake tests, leaving low stake ones little touched, too.

\section{References}

Alderson, J.C., \& Wall, D. (1993). Does washback exist? Applied Linguistics, 14, 115-129.

Alderson, J. C. \& Hughes, A. (1981). Issues in language testing ELT documents 111.

Alderson, J. C., \& Banerjee, J. (2002). Language testing and assessment (Part 2). Language Teaching, 35(02), 79-113. https://doi.org/10.1017/ S0261444802001751

Alderson, J. C., \& Banerjee, J. (2001). Language testing and assessment. Language Teaching, 34(Part I), 213-236. https://doi.org/10.1017/ S0261444801001707

Alderson, J.C., \& Wall, D. (1993). Does washback exist? Applied Linguistics, 14, pp. 115-129.

Ahmad, S., \& Rao, C. (2012). Examination washback effect: syllabus, teaching methodology and the learners 'Communicative Competence. Journal of Education and Practice, 3(15), pp.173-183. 
Antineskul, O., \& Sheveleva, M. (2015). Teachers' perceptions towards BEC exams in Russia: A qualitative study. Shevelava.

Bachman, L. F., Palmer, A. S. (1996). Language testing in practice: designing and developing useful language tests. Oxford Applied Linguistics. https:// doi.org/10.2307/328718

Barnes, M. M. (2016a). Washback and CLT. Centre for Applied Linguistics Research, 7(2).

Barnes, M. M. (2016b). The washback of the TOEFL iBT on English language programs in Vietnam. Australian Journal of Teacher Education, 41(7), 246. https://doi.org/10.14221/ajte.2016v41n7.10

Barnes, M. M. (2017). Washback: exploring what constitutes "good" teaching practices. Journal of English for Academic Purposes, 30, 1-12. https:// doi.org/10.1016/j.jeap.2017.10.003

Bailey, K. M. (1996). Washback in language testing education journal. New Jersey: Educational Testing Service, Princeton, New Jersey, RM-99-4. https://doi.org/10.11648/j. edu. 20150401.12

Borg, S. (2003). Teacher cognition in language teaching: A review of research on what languae teachers think, know, believe, and do. Language Teaching, 36(2), 81-109. https://doi.org/10.1017/ S0261444803001903

Borg, S. (2006). Teacher cognition and language education. Research and practice. London, UK: Continuum.

Bui, T. H. (2018). Washback of the proficiency assessment as exit requirement on non-English major students at a law school (Masters' Thesis). Retrieved from http://repository.ulis.vnu.edu. vn/bitstream/ULIS_123456789/1741/1/Bui\%20 Thanh\%20Huong.pdf

Bui, T. S. (2016). The test usefulness of the Vietnam's college English Entrance Exam (Master's Thesis). Korea University, Seoul.

Bullock, N. (2017). Learning \& testing alignment: towards positive washback. Powerpoint presentation at the ICAO LPRS - 10 years on: Progress or Pain? Dubrovnik.

Chen, L.M.D. (2002). Taiwanese junior high school English teachers' perceptions of the washback effect of the basic competence test in English (Unpublished Doctoral Dissertation). The Ohio Satate University, Ohio.

Chen, M. (2014). Postmethod pedagogy and its influence on EFL teaching strategies. English Language Teaching, 7(5), pp. 17-25. https:// doi.org/10.5539/elt.v7n5p17

Cheng, L, Watanabe, Y \& Curtis, A. (2004) (Eds). Washback in Language Testing: Research Contexts and Methods. New Jersey: Lawrence Erlbeaum Associates, Publishers. https://doi. org/10.4324/9781410609731
Cheng, L., Andrews, S., \& Yu, Y. (2011). Impact and consequences of school-based assessment (SBA): Students' and parents' views of SBA in Hong Kong. Language Testing, 7(2), 221-249. https:// doi.org/10.1177/0265532210384253

Cheng, L. (1999). Changing assessment: Washback on teacher perceptions and actions. Teaching and Teacher Education, 15(3), 253-271. https://doi. org/10.1016/S0742-051X(98)00046-8

Cheng, L. (2008). Washback, Impact and Consequences. Encyclopedia of Language and Education: Language Testing and Assessment, (2nd Ed.) (7), 349-364. https://doi.org/10.1007/978-0-387-30424-3

Cheng, L. \& Curtis, A. (2012). Test impact and washback: Implications for teaching and learning. In S. Coombe, Christine; Davidson, Peter; O'Sullivan, Barry; Stoynoff (Eds.), The Cambridge Guide to Second Language Assessment. New York: Cambridge University Press.

Cheng. L. (2014). The washback effect of a pbublic examination change on teacher's perceptions toward their classroom teaching. In C., Liying, W., Yoshinori., A., Curtis (Eds.). Washback in Language Testing: Research Context and Method (pp.19-26). Marwah, New Jersey: Lawrance Erlbaum Associates, Inc. Publishers.

Cheng, L., Sun, Y. \& Ma, J. (2015). Review of washback research literature within Kane's argument-based validation framework. Language Teaching, 48(4), 436-470. https://doi.org/10.1017/ S0261444815000233

Danielson, C. (1996). Enhancing professional practice: A framework for teaching. Alexandria, VA: Association for Supervision and Curriculum Development.

Fives, H., Gill, M. G. ( 2014). International handbook of research on teachers' beliefs. London: Taylor \& Francis Ltd.

Furaidah, S., A., \& Widiati, U. (2015). Washback of English national examination in the Indonesian context Utami Widiati. Teflnjournal, 26(1), pp. 36-58. https://doi.org/10.15639/teflinjournal. v26i1/36-58

Green, A. (2007). IELTS Washback in Context: Preparation for academic writing in higher education. Studies in Language Testing 25. Cambridge: Cambridge University Press.

Green, A. (2013). Washback in language assessment. International Journal of English Studies, 13(2), 39-51.

Hamp-Lyons, L. (1997). Washback, Impact and Validity: Ethical Concerns. Language Testing, 14(3), 295303. Hsieh, C. (2017). The Case of Taiwan: Perceptions of College Students About the Use of the TOEIC ${ }^{\circledR}$ Tests as a Condition of Graduation. In ETS Research Report Series (pp. 1-12). 
Hsu, H. F. (2009). The impact of implementing English proficiency tests as a graduation requirement at Taiwanese universities of technology (Doctoral Dissertation) Retrieved from http://etheses. whiterose.ac.uk/576/

Hughes, A. (2003). Testing for Language Teachers. Australian Review of Applied Linguistics (Vol. 27). https://doi.org/10.1017/CBO9780511732980

Kumaravadivelu, B. (1994). The postmethod condition: Emerging strategies for second/foreign language teaching [J]. TESOL Quarterly, 28, 27-47.

Lam, H P (1994) Methodology washback--an insider's view. In Nunan, D., Berry, R. and Berry, V. (Eds) Bringing about change in language education: Proceedings of the International Language in Education Conference (pp. 83-120) Hong Kong: University of Hong Kong.

Latimer, D. G. (2009). Washback effects of the Cambridge Preliminary English Test at an Argentinean bilingual school. Unpublished paper.

Le, T.H.D. (2017). Exploring teachers' perceptions and practices of English for Specific Purposed (ESP) in Vietnames context (Doctoral Dissertation). Retrieved from ULIS Doctoral Dessertations.

Le, V. C. (2011). Form-Focus instruction: A case study of Vietnamese teachers' beliefs and practices (Doctoral Disseration). Retrieved from https:// researchcommons.waikato.ac.nz/bitstream/ handle/10289/5253/thesis.pdf;jsessionid $=159888 \mathrm{~B}$ F75888614104738591EE443CF? sequence $=3$

Lemmetti, J. (2014). What makes a good language test in EFL? Gôteborg Universite.

Liauh, Y.-H. E. (2011). A study of the perceptions of English faculty and students of Exit English Examinations at Taiwan's technological and vocational higher education institutions (Doctoral Dessertation). Retrieved from http://search. proquest.com/docview/874150865?accountid= 14548\%5Cnhttp://metadata.lib.hku.hk/hku?url ver=Z39.88-2004\&rft_val_fmt=info:ofi/fmt:kev:m tx:dissertation \&genre $=$ dissertations $+\% 26+$ thes

Mahmoudi, L. (2013). Iranian Pre-university English Teachers' Perceptions and Attitudes towards the Iranian National University Entrance Exam : A Washback Study. International Journal of Education \& Literacy Studies, 1(2), 309-310. https://doi.org/10.7575/aiac.ijels.v.1n.2p.47

Manjarrés, N. B. (2004). Washback of the foreign language test of the state examinations in Columbia: A case study. Arizona Working Papers in SLAT, 12, 1-19.

McNamara, T. (2000). Language Testing. Oxford, UK: Oxford University Press.

Messick, S. (1996). Validity and washback in langauge testing. Language Testing. Retrieved from http://ltj. sagepub.com/content/13/3/241.short

Nguyen, P.N., Griffin, P. \&, \& Izard, J. (2008). Toward beneficial washback effects of a test, 1-27.
Nguyen, P. N. (1997). Washback effects of international English language testing system at the Vietnam National University (Doctoral Dissertation) University of Melbourne, Oppenheim.

Nguyen, Thị Linh. (2017). Impacts of Vietnamese standardised test of English proficiency on the first year students' English language learning. Đề án ngoại ngũ quốc gia 2020. Retrieved from https://dean2020.edu.vn/vi/news/Tin-tuc/impactsof-vietnamese-standardized-test-of-englishproficiency-vstep-on-the-first-year-studentsenglish-language-learning-410.html

Nguyen, T. L. (2017). The Effects of VSTEP on Students' Learning Motivation. Kỷ yếu hội thảo khoa học quốc gia dành cho học viên cao hoc và nghiên cúu sinh lần thứ nhất (GRS) 2017. Graduate Research Symposium (GRS) 2017.

examination on teachers ' instructional practices, materials and curriculum. Leicester: University of Leicester.

Onaiba,A.M.E.(2013). Investigating the washback effect of a revised EFL public examination on teachers 'instructional practices, materials and curriculum. Leicester: University of Leicester.

Pajares, M. F. (1992). Teachers- beliefs and educational research: Cleaning up a messy construct. Review of Educational Research, 62(3), 307-332.

Pan, Y. (2009). A review of washback and its pedagogical implications. Journal of Science, Foreign Languages, 25 (February), 257-263.

Pan, Y. C., \& Newfields, T. (2012). Tertiary EFL proficiency graduation requirements in Taiwan: A study of washback on learning. Electronic Journal of Foreign Language Teaching, 9(1), 108-122.

Papakammenou, I. (2013). Examining Washback in Multi-exam Preparation Classes in Greece (A Focus on Teachers' Teaching practices).pdf. EALTA Conference Turkey.

Peña Jaenes, V. (2017). Testing Writing: the Washback Effect on English Courses. The Grove - Working Papers on English Studies (Vol. 24). Jaén, Andalucía, Spain.

Pierce, B. N. (1992). Demystifying the TOEFL reading test. TESOL Quarterly. 26(4), pp. 665-691.

Rahman, S. (2014). Teachers Suffering from Exam Washback Effect: Exclusion of Practicing Speaking and Listening Skills in English Classes. Dhaka: BRAC University.

Read, J., \& Hayes, B. (2003). The Impact of IELTS on Preparation for Academic Study in New Zealand. IELTS Research Reports (Vol. 4). Canberra. Retrieved from https://search.informit.com.au/docu mentSummary;dn=909013632781357;res=IELHSS

Richard, C. J. (2006). Communicative Language Teaching Today. New York: Cambridge University Press. 
Richards, J. C., \& Lockhart, C. (2007). Reflective Teaching in Second Language Classrooms. The Modern Language Journal (Vol. 79). New York: Cambridge University Press. https://doi. org/10.2307/329404

Sadighi, S., Yamini, M., \& Bagheri, M. S. (2018). Investigating preuniversity EFL teachers, perceived wash-back effects of university entrance exams and teaching materials on students ' learning objectives and teachers ' class performance. Cogent Social Sciences, 00(00), 1-16. https://doi.org/10.10 80/23311886.2018.1546448

Saif, S. (2006). Aiming for positive washback: a case study of international teaching assistants. Language Testing, 23(1), 1-34. https://doi. org/10.1191/02655322061t322oa

Saville, N. D. (2009). Developing a model for investigating the impact of language assessment within educational contexts by a public examination provider. Bedfordshire: University of Bedfordshire.

Salehi, H., Yunus, M. M., \& Salehi, Z. (2012). Teachers' perceptions of high-stakes tests: a washback study. International Journal of Social Science and Humanity (IJSSH), 2(1), 70-74.

Shih, C.-M. (2007). A new washback model of students' learning. Canadian Modern Language Review, 64(1), 135-161. https://doi.org/10.3138/ cmlr.64.1.135

Shih, C.-M. (2009). How tests change teaching: A model for reference. English Teaching: Practice and Critique, 8(2), 188-206.

Shohamy, E., Or, I. G., \& May, S. (2017). Language testing and assessment. Switzeland: Springer. https://doi.org/10.1007/978-319-02261-1

Shohamy, E. (1993). The power of tests : The impact of language tests on teaching and learning. NFLC occasional paper. The National Foreign Language Center, 1-20. Retrieved from https://eric. ed.gov/?id=ED362040

Shohamy, E. (1998). Critical language testing and beyond. Studies in Educational Evaluation, 24(4), 331-345. https://doi.org/10.1016/S0191491X(98)00020-0

allr.ir/index.php/JALLR/article/view/63

Tayeb, Y., Abd Aziz, M., Ismail, K., \& Khan, A. (2014). The Washback Effect of General of the General Secondary English Examinations (GSEE) on teaching and Learning. GEMA Online Journal of Language Studies, 14(3), 83-103.

Tayeb, Y. A., Abd Aziz, M. S., Ismail, K. (2018). Predominant Washback of the General Secondary English Examination on Predominant Washback of the General Secondary English Examination on Teachers. International Journal of Engineering and Technology, 7(August). https://doi.org/10.14419/ ijet.v7i3.21.17211

Taylor, L. (2005). Washback and impact. ELT Journal, 59(2), 154-155. https://doi.org/10.1093/eltj/cci030

Thuy Nhan. (2013). The TOEIC ${ }^{\circledR}$ Test as an Exit Requirement in Universities and Colleges in Danang City, Vietnam: Challenges and Impacts. International Journal of Innovative Interdisciplineary Research, 2(June), 33-50.

Tran, T. D. (2016). Impact of using TOEIC as an exit requirement at a public university in Vietnam. In 4th British Council New Directions in English Language Assessment: Standardised Testing and Proficiecy Scales. Retrieved from https:// www.britishcouncil.vn/sites/default/files/new directions_2016_dr_duyen_tran_impact_of_ using_toeic_as_an_exit_requirement_at_a_public_ university_in_vietnam.pdf

Tsagari, D. (2007). Review of washback in language testing: How has been done? What more needs doing? Lancaste: Lancaster University, UK.

Tsagari, D. (2011). "Washback of a high-stakes English exam on teachers" perceptions and practices"." Selected Papers from the 19th ISTAL, (1996), 431445.

$\mathrm{Vu}$, T. P. A. (2016). 25 years of language assessment in Vietnam : Looking back and looking forward. In New Directions in English Language Assessment in Vietnam. Retrieved from https:/www. britishcouncil.vn/.../new_directions_2016_dr_vu_ thi_phu...

Wall, D., \& Horák, T. (2006). The impact of Changes in the TOEFL Examination on Teaching and Learning in Central and Eastern Europe: Phase 1, The Baseline Study. Retrieved from https://www.ets. org/Media/Research/pdf/RR-06-18.pdf

Wang, J. (2010). A study of the role of the "teacher factor" in washback (Dooctoral disseratation). Retrieved from http://digitool.library. mcgill.ca/webclient/StreamGate?folder $\mathrm{id}=0 \& \mathrm{dvs}=1565578944761 \sim 588$

Watanabe, Y. (2004). Methodology in Washback Studies. In C., Liying, W., Yoshinori \& A., Curtis (Eds.), Washback in Language Testing: Research Context and Method (pp.19-26). Marwah, New Jersey: Lawrance Erlbaum Associates, Inc. Publishers.

Wenyuan, Z. (2017). The washback effect of CET spoken English test upon college English teaching. Canadian Social Science, 13(1), 62-68. https://doi. org/10.3968/9241

Zeng, H. (2015). Teacher beliefs as a complex system: English language teachers in China. NY: Springer. 


\title{
KHẢO CÚU VỀ CÁC MÔ HÌNH VÀ NGHIÊN CÚU THỰC NGHIẸM Ở VIÊTT NAM VÀ TRÊN THẾ GIỚI VỀ TÁC ĐộNG DỘI NGƯợC CỦA BÀI THI TỚI GIÁO VIÊN DẠY TIẾNG
}

\author{
Đinh Minh Thu \\ Đại học Hải Phòng \\ 171 Phan Đăng Lưu, Kiến An, Hải Phòng, Việt Nam
}

Tóm tắt: Tác động dội ngược hay ảnh hưởng của bài thi tới việc dạy và học đã trở thành chủ đề nghiên cứu hấp dẫn ở lĩnh vực kiểm tra và đánh giá ngôn ngữ trong vòng hai mươi năm trở lại đây do ứng dụng quan trọng của những nghiên cứu này giúp các nhà hoạch định chính sách và những người thực thi chính sách đảm bảo đánh giá có tính chính xác và công bằng. Hiện nay, những nghiên cứu này được nhiều nhà nghiên cứu ở Việt Nam quan tâm hơn do yêu cầu cải tiến công tác kiểm tra đánh giá được Đề án Ngoại ngữ Quốc gia 2020 (kéo dài đến 2025) đặt ra. Tác động dội ngược diễn ra một các tích cực hoặc tiêu cực tùy theo việc nó đẩy mạnh hay ngăn cản hiệu quả học tập. Giáo viên được coi là nhân tố tiên phong trong cơ chế tác động. Chỉ có một mô hình về tác động dội ngược tới giáo viên được Shih (2009) đề xuất. Bài viết này mục đích khảo cứu các mô hình tác động dội ngược, bao gồm mô hình của Shih (2009), để xây dựng lên một mô hình tác động dội ngược của bài thi tới nhận thức và hành động của giáo viên. Mô hình mới này sẽ được sử dụng để khảo cứu các nghiên cứu thực nghiệm trước đây về tác động dội ngược trong và ngoài Việt Nam giúp tìm ra những điểm các nhà nghiên cứu đã tìm ra và cả những điểm chưa được nghiên cứu. Phương pháp nghiên cứu trong bài viết này là định tính thông qua phân tích hơn bốn mươi tài liệu gồm nhiều thể loại như sách, luận văn, luận án, bài báo, v.v. Nội dung thảo luận chính của bài viết gồm hai phần: khảo cứu các mô hình lý thuyết và khảo cứu các nghiên cứu thực nghiệm. Kết quả khảo cứu chỉ ra rằng tác động dội ngược của bài thi tới nhận thức của giáo viên liên quan tới nhận thức của giáo viên về bài thi, về năng lực ngôn ngữ của người học, về nội dung và phương pháp giảng dạy, về việc giáo viên phát triển chuyên môn. Thêm vào đó, tác động dội ngược của bài thi lên hành động của giáo viên bao gồm việc họ lựa chọn nội dung giảng dạy, phương pháp giảng dạy và phát triển chuyên môn. Yếu tố phát triển chuyên môn là yếu tố mới trong khung nghiên cứu mới tạo ra. Điều này có ý nghĩa quan trọng làm tăng nhận thức của giáo viên về việc phát triển chuyên môn. Bài viết này mong muốn đóng góp cho việc làm rõ bức tranh về nghiên cứu tác động dội ngược của bài thi giúp các nhà nghiên cứu, giáo viên và quản lý có quan tâm đến lĩnh vực này hiểu rõ hơn tình hình nghiên cứu hiện nay.

Tì khóa: tác động dội ngược, mô hình tác động dội ngược, bài kiểm tra ngôn ngữ, nhận thức của giáo viên, hành động của giáo viên 